\title{
Health needs and health seeking behaviour of Internally Displaced Persons in Dalori camp, Maiduguri, Borno State, Nigeria
}

\author{
*Faronbi J.O. ${ }^{1}$, Akinyoola O.D. ${ }^{2}$, Faronbi G.O. ${ }^{1}$, Adegbola G.A. ${ }^{1}$, and Bello C.B. ${ }^{3}$
}

\begin{abstract}
Objectives: In recent years, thousands of people have been displaced due to conflict and have been forced to live in crowded camps. The study assessed the common health problems, health needs and healthseeking behaviours of internally displaced persons in Nigeria.
\end{abstract}

Methods: A cross-sectional descriptive design was used to study 240 randomly selected respondents using an interviewer-administered semi-structured questionnaire. Data collected were analysed using descriptive and inferential statistical techniques.

Results: The prevalence of communicable disease outbreak was $59.2 \%$ and common health problems of the IDPs were malaria $(97.9 \%)$, cold and catarrh $(65.8 \%)$, heart diseases $(56.7 \%)$, and diarrhoea $(53.3 \%)$. Findings also revealed that access of IDPs to potable water, insecticide-treated nets (ITN), blankets and health care facility, as well as waste disposal, were generally poor. A large proportion of the respondents reported overcrowding (45.8\%), inconducive housing (94.6\%), dirty environment $(54.6 \%)$ and poor food distribution (90\%) in the camp. Furthermore, factors that predicted poor health among the IDPs include: educational status (OR: $0.397, p=0.010)$, poor water supply $(\mathrm{OR}: 0.343, \mathrm{p}=0.006)$, hand washing $(\mathrm{OR}$ : $7.064, \mathrm{p}=0.004)$, and overcrowding (OR: $0.055, \mathrm{p}=0.001)$.

Conclusion: This study concluded that ccommon health problems among the IDPs were malaria, cold and catarrh, heart diseases and diarrhoea and their health needs include lack of access to potable water and inadequate health care services.

Keywords: Health-seeking behaviour, Health - need, Internally Displaced Persons, Nigeria

\author{
*Corresponding author \\ Faronbi J.O. \\ http://orcid.org/0000-0003-3392-4472 \\ Email:,jfaronbi@cartafrica.org
}

${ }^{1}$ Department of Nursing Science, College of Health Sciences, Obafemi Awolowo University, Ile-Ife, Nigeria

${ }^{2}$ Department of Nursing Science, Osun State University, Osogbo, Nigeria

${ }^{3}$ Department of Nursing Science, College of Medicine \& Health Sciences Afe Babalola University, Ado-Ekiti, Nigeria 


\title{
Besoins de santé et comportement de recherche de santé des personnes déplacées dans leur propre pays Personnes dans le camp de Dalori, Maiduguri, Etat de Borno, Nigéria
}

\author{
*Faronbi J.O. ${ }^{1}$, Akinyoola O.D. ${ }^{2}$, Faronbi G.O. ${ }^{1}$, Adegbola G.A. ${ }^{1}$, and Bello C.B. ${ }^{3}$
}

\begin{abstract}
Resume
Objectifs: Au cours des dernières années, des milliers de personnes ont été déplacées à cause du conflit et ont été forcées de vivre dans des camps surpeuplés. L'étude a évalué les problèmes de santé courants, les besoins en matière de santé et les comportements en matière de santé des personnes déplacées à l'intérieur du Nigéria.
\end{abstract}

Méthodes: Un modèle descriptif transversal a été utilisé pour étudier 240 répondants choisis au hasard à l'aide d'un questionnaire semi-structuré administré par un enquêteur. Les données recueillies ont été analysées à l'aide de techniques statistiques descriptives et inférentielles.

Résultats: La prévalence des épidémies de maladies transmissibles était de 59,2\% et les problèmes de santé courants des personnes déplacées internes étaient le paludisme (97,9\%), le rhume et le catarrhe $(65,8 \%)$, les maladies cardiaques $(56,7 \%)$ et la diarrhée $(53,3 \%)$. Les résultats ont également révélé que l'accès des personnes déplacées à l'eau potable, aux moustiquaires imprégnées d'insecticide, aux couvertures et aux établissements de soins de santé, ainsi qu'à l'élimination des déchets, était généralement médiocre. Une proportion importante des répondants ont déclaré surpeuplement $(45,8 \%)$, logements incontrôlables $(94,6 \%)$, environnement sale $(54,6 \%)$ et distribution de nourriture médiocre $(90 \%)$ dans le camp. En outre, les facteurs prédictifs d'une santé médiocre parmi les personnes déplacées incluent: le niveau d'instruction (OR: 0,397, $\mathrm{p}=0,010)$, un approvisionnement en eau insuffisant (OR: $0,343, \mathrm{p}=$ 0,006), le lavage des mains (OR: 7,064, $p=0,004)$ et surpeuplement (OR: 0,055, $p=0,001)$.

Conclusion: cette étude a conclu que le paludisme, le rhume et le catarrhe, les cardiopathies et la diarrhée étaient les problèmes de santé les plus courants parmi les personnes déplacées à l'intérieur du territoire.

Mots-clés: Comportement en quête de santé, besoins en matière de santé, personnes déplacées dans leur propre pays, Nigéria

\footnotetext{
*Auteur principal

Faronbi J.O.

http://orcid.org/0000-0003-3392-4472

Email:,jfaronbi@cartafrica.org

${ }^{1}$ Department of Nursing Science, College of Health Sciences, Obafemi Awolowo University, Ile-Ife, Nigeria

${ }^{2}$ Department of Nursing Science, Osun State University, Osogbo, Nigeria

${ }^{3}$ Department of Nursing Science, College of Medicine \& Health Sciences Afe Babalola University, Ado-Ekiti, Nigeria
}

Research Journal of Health Sciences subscribed to terms and conditions of Open Access publication. Articles are distributed under the terms of Creative Commons Licence (CC BY-NC-ND 4.0). (http://creativecommons.org/licences/by-nc-nd/4.0).

http://dx.doi.org/10.4314/rejhs.v7i3.9 


\section{INTRODUCTION}

Thousands of people are displaced globally every year due to armed conflict $(1,2)$. They are forced to flee their homes in search of protection; some find refuge with families and friends, but most are crowded into camps where they become victims of further violence, mental stress, and disease (3). Internally Displaced Persons (IDPs) refer to individuals who are victims of the displacement due to violence, or natural disasters and have not been able to settle back in their place of origin (4-6).

The displacement of persons has been a serious problem in Nigeria and the world as a whole. The total number of displaced persons worldwide is currently estimated at about fifty million, with the majority of these people in Africa and Asia; approximately 26 million of these IDPs were displaced within the borders of their country of nationality (4-7).

Recently, Nigeria has experienced large-scale involuntary internal displacement caused by the terrorist group (Boko Haram) insurgency, especially in the North Eastern part of the country. The movement and settlement in improvised camps make the IDPs even more vulnerable. Internal Displacement Monitoring Centre argued that the IDPs are probably the largest group of vulnerable people in the world; they are often denied fundamental human rights; living in squalor and lacking physical security and freedom of movement (8). Moreover, IDPs are unable to improve their situation, since limited access to means of livelihood prevents them from becoming self-reliant.

In 2014, the number of IDPs in Nigeria had risen to 3.3million persons, making Nigeria the largest country in sub-Saharan Africa with total IDP populations and among the top five worldwide $(7,9)$. The figure is still rising owing to the increase in the occurrence of armed conflicts in many part of the country. The problem has persisted and become recalcitrant, leading to 279,000 new displacements and bringing the total number of IDPs still displaced by June 2017 to 3.7 million (10). However, a vast majority of IDPs in Nigeria reside in overcrowded IDP camps across the disturbed northern regions. These camps are mainly school facilities and empty government buildings with few or no basic amenities. Many IDPs remain deprived of the right to the necessities of life especially with regards to their health, in addition to the psychosocial impact on their well-being (11).

Although many studies have been conducted among the IDPs, little has been documented in the area of health needs and health seeking behaviours of IDPs. This study, therefore, assessed the common health problems, health needs, hygienic practices as well as healthseeking behaviours of the IDPs. It also determined factors associated with poor health status among the IDPs. The findings of this research may serve as a tool for health education of the IDPs on personal hygiene and environmental sanitation. It will also assist policymakers in their quest to design programmes which aims at improving the live and health conditions of IDPs living in camps all over Nigeria.

\section{MATERIALS AND METHODS}

Design: The study employed a cross-sectional research design.

Study setting: The study was conducted among the residents of Dalori IDPs camp, Maiduguri, Borno State. Dalori camp is one of the 32 IDP camps in Borno State, Nigeria (12). The untarred road that leads to the camp houses a handful of small retail shops. Most of the IDPs in the camp lived in tents made from locally sourced materials such as bags of cement, sacks and sticks, totalling 700 tents. They rely largely on foods donated by NGOs, religious organizations and individual philanthropists who come in to visit (13-14).

Sample size determination: The study's sample size was estimated using the formula: $n=p(1-p)$ $\mathrm{z}^{2} / \mathrm{D}^{2}$. Where $\mathrm{n}=$ sample size; $\mathrm{P}=$ proportion of the phenomenon estimated at $11 \%, Z=$ standard normal deviate where confidence level is 1.96 at $95 \% ; \mathrm{D}=$ absolute precision or error margin $(5 \%)$ (15). Approximately $11 \%$ of residents in the troubled Local Government Areas in Borno State are in displacement (7). Using a proportion of people in displacement as $11 \%$ and $10 \%$ nonresponse rate yielded a sample size of 165 . However, the sample was increased to 240 to increase the power of the study.

Sampling technique: A multi-staged probability sampling technique was used to select the respondents; firstly, the entire camp was clustered into four cardinal zones - north, south, west and east, each containing one hundred and seventy - five (175) tents. Secondly, sixty (60) tents were drawn from each cluster using a systematic random technique $(\mathrm{k}=3)$, therefore, every third tent was selected. Finally, in each of the selected tents, one willing resident, male or female aged eighteen (18) years and above was 
selected using a simple ballot method. A total of 240 subjects were therefore drawn from the whole camp.

Research Instrument: Data was collected with a validated semi-structured intervieweradministered questionnaire. The instrument was translated back-to-back to Hausa language. The instrument collected information on respondents' socio-demographic characteristics; duration of stay in camp; common health problems experienced; their perceived health needs; hygienic practices and health seeking behaviours. Health status was rated as poor health determined by the presence of at least one of the common health problems listed in table 2 versus good health.

Validity and Reliability of the research instrument: The face and content validity of the questionnaire were ascertained through scrutiny by experts in the field of Nursing, Public health, Epidemiology and Statistics. The reliability of the instrument was determined with a test-retest method following a pilot study of 10 respondents from Bakassi IDPs' camp, Borno State. The instrument yielded a Cronbach's alpha 0.70, therefore, it was deemed suitable for use in the current study.

Method of data collection: Data was collected by two trained research assistants who were local residents of Dalori town and who were proficient in English and the local languages (Hausa and Kanuri). Selected residents were approached individually and the purpose of the study was explained to them. Each of the items with the appropriate options was read to the respondents and responses were given accordingly.

Ethical consideration: Ethical clearance for the study was obtained from the Human Research Ethics Committee, Institute of Public Health, Obafemi Awolowo University, Ile-Ife (IPH/OAU/12/1017). Also, approval was obtained from the local authorities and managers of the IDP camp. In addition, informed consent was obtained from each respondent after the purpose of the study was explained to them, prior to data collection.

Data analysis: Data collected were analysed descriptively and inferentially using Stata 12.0 statistical program and the level of statistical significance was set at $p \leq 0.05$.

\section{RESULTS}

A total of 240 respondents were recruited into the study. Findings revealed that the age of the respondents ranged from 18 to 57 years with a mean (SD) of $34.47 \pm 11.14$ years. More than $30 \%$ of the respondents were aged between $21-$ 30 years and female gender accounts for more than half of the respondents. Almost half (47.5\%) of the respondents practice Islam and were already married (46.3\%). A sizable proportion $(37.1 \%)$ of them had no formal education while more than two - thirds of them $(72.1 \%)$ had been in the camp for more than 5 months (Table1).

Results from the study showed that almost all the respondents (99\%) reported to have experienced at least one form of ailment or the other in the past one to three months. Common health problems among the IDPs were malaria fever $(97.9 \%)$, infection such as common cold and catarrh $(65.8 \%)$, heart diseases $(56.7 \%)$ and diarrhoea $(53.3 \%)$. Also, a large proportion of the respondents $(80.8 \%)$ claimed to have witnessed incidence of communicable disease outbreak in the camp before (see table 2).

The hygienic practices of the IDPs are presented in table 3 . It revealed that the major source of water in the camp is well/borehole (44.6\%), and $80.0 \%$ of the respondents said that they did not treat the water before use and $84.6 \%$ did not practice regular hand washing. More than three-quarters $(76.3 \%)$ practiced open dumping of refuse. All the respondents claimed they did not consume regular meals at the camp. This may be as a result of poor access to food supply as they only depend on aid by humanitarian organisations. Similarly, two-third $(66.6 \%)$ claimed that they did not have insecticide-treated nets (ITN). In addition, there was an absence of enforcement of good hygiene and environmental sanitation in the camp (93.8\%) (Table 3).

Findings from the study also revealed the living and environmental conditions of the camp. These include: overcrowding (45.8\%) unconducive housing (94.6\%), lack of privacy and dirty environment (54.6\%). Majority of the respondents $(90 \%)$ also claimed that they experienced poor food distribution both in regularity of supply, as well as adequacy in quality and quantity (Table 4).

Table 5 presents the coping strategies employed by camp residents. It revealed that $28.3 \%$ were involved in menial jobs. They were involved in activities such as sweeping (50\%), hawking $(20.6 \%)$ and truck pushing (17.6\%) while $11.8 \%$ were involved in digging well for residents of the neighbouring villages. In 
addition, $15.8 \%$ of the participants were involved in sexual activities in the camp.

Results on the health-seeking behaviours of the respondents are presented in table 6. More than $60 \%$ of the respondents reported visiting hospital/health worker when they were ill; however, a majority $(82.9 \%)$ of the respondents reported inadequate health facility, in time of human and material resources to meet the health need of the people within the camp (see Table 6).

Logistic regression analysis was done to predict the health status from demographic characteristics of respondents and other factors. These variables significantly predicted poor health, $X^{2}(10)=211.88, \mathrm{p}<0.000$ and $\mathrm{R}^{2}=0.69$. The following factors: educational status (OR: $0.397, p=0.010)$, source of water supply (OR: $0.343, \mathrm{p}=0.006)$, hand washing (OR: 7.064, $\mathrm{p}=$ $0.004)$, and overcrowding (OR: $0.055, \mathrm{p}=0.001$ ) were statistically significant (Table 7).

\section{DISCUSSION}

This study assessed the common health problems, health needs, hygienic practices and predictors of poor health status among the residents of Dalori IDP camp. The poor general state of the camp, evidenced by overcrowding, unhealthy, unhygienic and in-hospitable environments, indicates economic impoverishment brought about by the displacement. Previous studies also agreed with these findings $(17,18)$. In addition, there were reports of the breakout of epidemic and widespread of diseases among the residents especially among children and women which is often complicated by lack of healthcare facilities. Similarly, incidence of communicable disease outbreak has also been reported within the Ugandan IDP camp $(19,20)$.

The lack of basic infrastructure in the IDP camps is indeed a substantial problem which collective efforts of governments, nongovernmental organization and individual philanthropy have not adequately addressed (21). Many countries still lack the appropriate resources to address these health needs inherent in IDP populations, which Fielden (4) has described as very precarious with little or no hope for a durable solution. Paquet and Hanquet (22) observed that the public health implications of infectious diseases in IDP camps are still difficult to address both in developed and developing nations.

Findings from this study also revealed an alarming incidence of infectious diseases such as malaria, common cold and catarrh and diarrhoea among the residents of Dalori camp. The most prevalent health condition is malaria which may have been heightened by unavailable or insufficient Insecticide Treated Nets, which would have provided covering against mosquitoes bite at night. Several authors have also supported the assertion that malaria fever is the highest ranking health problem of IDPs camp across Africa $(18,23)$.

Infectious diseases occurrence in Dalori camp is particularly prevalent among the IDPs owing to infrastructural collapse, deplorable environmental condition, lack of basic health knowledge, and/or promotion practice. It also includes poor feeding in the camp which could result in weakening of their immune systems thus making them to be more susceptible to infection.

Furthermore, the results revealed that the residents lacked access to potable water and were unable to make the available subterranean water fit for drinking. In addition, the practice of effective and regular hand washing particularly after using the toilet is very poor. This was also complicated by the lack of a system for enforcing hygiene practices and environmental sanitation among the IDPs. These findings agree with previous study that revealed that environmental problems including water, sanitation, and overcrowding are responsible for health-related problem among the IDPs (20). Findings from study conducted by Mooney et al revealed that IDPs lack access to food, water and Medicare due to shortages (24). This was also supported by other authors the findings of $(23,25)$ who reported that most of the IDP camps are characterised by the absence of shelter, food shortages and poor access to healthcare. This may be so because each unit of the camps contains more than an average number of people expected in a family setting. Thus, making planning and logistics difficult for government and well spirited individuals.

Some camp residents engage in negative and unwholesome behaviours such as promiscuous sexual activities to earn a means of survival. Durosaro and Ajiboye (26) documented in their study among the IDPs that female adolescents succumb to commercial sex and sexual molestation and the male also give themselves to being recruited for armed conflicts in order to survive harsh economic realities. Furthermore, strategies employed by the respondents in meeting their health needs include visiting the hospital/health workers within the camp or in the neighbouring village. The also patronise traditional healers as well. This agree 
with the findings of Roberts and Odong (20) who reported that respondents use biopsycho-social health services such as health centres, hospitals, and health workers. However, the available facilities in this camp were largely inadequate, crippled and non-functional.

\section{CONCLUSION}

The findings of this study revealed that residents of IDP camps live in a deplorable and unhygienic environment which exposes them to a constant outbreak of infectious disease. Factors such as educational status, water supply, hand washing, overcrowded living conditions and dirty environment significantly contributed to the poor IDPs' health status. It is therefore recommended that efforts from all quarters should be geared towards reinforcing hygienic practices in the camp, providing adequate water supply, ameliorating overcrowding and providing adequate access to healthcare.

\section{Conflict of interest: None to declare}

\section{REFERENCES}

1. United Nations High Commissioner for Refugees. Global Trends: Refugees, Asylumseekers, Returnees, Internally Displaced and Stateless Peoples. 2009 Accessed 25/09/2019 Available from: https://www.unhcr.org.

2. United Nations High Commissioner for Refugees. Global Trends n Forced Displacement in 2018. 2018 Accessed 27/09/2019. Available from:

3. Black R, Arnell NW, Adger WN, Thomas D, Geddes A. Migration, immobility and displacement outcomes following extreme events. Environmental Science \& Policy. $2013 ; 27:$ S 32 - S 43 d o i 10.1016/j.envsci.2012.09.001

4. Fielden A. Ignored Displaced Persons: the plight of IDPs in urban areas. Accessed 27/09/2019 from www.unhcr.org. 2008

5. World Health Organisation. Internally Displaced Persons, Health and WHO Humanitarian Affairs Segment ECOSOC [Internet]. 2000 Accessed 27/09/2019. Available from: apps.who.int.

6. Shultz JM, Garfin DR, Espinel Z, Araya R, Oquendo MA, Wainberg ML, et al. Internally displaced "victims of armed conflict" in Colombia: the trajectory and trauma signature of forced migration. Current psychiatry reports. 2014;16(10):475 doi 10.1007/s11920-0140475-7

7. Lanshie EN, Henry YB. Boko haram insurgency, internally displaced persons and humanitarian response in northeast Nigeria”. International Journal of Humanities and Social Studies. 2016;4(8):141-50
8. Internal Displacement Monitoring Centre (IDMC). Global Report on Internal Displacement 2019. Accessed 26/09/2019 http://www.internal-displacement.org/globalreport/grid2019/2019.

9. Albuja S. Criminal Violence, Displacement and Migration in Mexico and Central America. Humanitarian Crises and Migration: Routledge; 2014. p. 113-37.

10. UNHCR. Nigeria Situation, Supplementary Appeal. Geneva. Accessed 27/09/2019 from https://wwwunhcrorg/597704b87pdf. 2017

11. Lee C, Nguyen AJ, Russell T, Aules Y, Bolton P. Mental health and psychosocial problems among conflict-affected children in Kachin State, Myanmar: a qualitative study. Conflict and Health. 2018;12(1):39

12. Premium Times Nigeria. "Borno still has 32 IDP camps despite return of some displaced persons NEMA. 2016-11-01. Accessed 26/09/2019 f $\quad \mathrm{r} \quad \mathrm{o} \quad \mathrm{m}$ https://www.premiumtimesng.com/regional/nn orth-east/214179-borno-still-32-idp-campsdespite-return-displaced-persons-nema.html. 2016.

13. Mirth AO. Experiences of Internally Dislaced Persons A Case Study of Bama and Gwoza Durumi Abuja Nigeria The Hague, The Netherlands: Erasmus University; 2015 M A https://thesis.eur.nl

14. Olaniyan O, Olayiwola S, Odubunmi S. The impact of health expenditure on the elderly in Nigeria. Pakistan Journal of Social Sciences. 2011;8(4):212-8

15. Naing L, Winn T, Rusli B. Practical issues in calculating the sample size for prevalence studies. Archives of orofacial Sciences. 2006;1(1):9-14

16. StataCorp L. Stata/SE Version 12.1 [Computer Software]. College Station, TX: Stata Corp, LLP. 2011

17. Getanda EM, Papadopoulos C, Evans H. The mental health, quality of life and life satisfaction of internally displaced persons living in Nakuru County, Kenya. BMC public health. 2015;15(1):755

18. Roberts B, Ocaka KF, Browne J, Oyok T, Sondorp E. Factors associated with the health status of internally displaced persons in northern Uganda. Journal of Epidemiology \& Community Health. 2009;63(3):227-32

19. Joshua IA, Biji BD, Gobir AA, Aliyu AA, Onyemocho A, Nmadu AG, et al. Social characteristics and risk factors for diseases among internally displaced persons: A study of stefano's foundation camp in Jos, Nigeria. Archives of Medicine and Surgery. 2016;1(2):42

20. Roberts B, Odong VN, Browne J, Ocaka KF, Geissler W, Sondorp E. An exploration of social determinants of health amongst internally displaced persons in northern Uganda. Conflict and health. 2009;3(1):10 
21. United Nations Office for the Coordination of Humanitarian Affairs. Nigeria Humanitarian Needs Overview 2014-2016. 2014

22. Paquet C, Hanquet G. Control of infectious diseases in refugee and displaced populations in developing countries. Bulletin de l'Institut Pasteur. 1998;96(1):3-14

23. Owoaje ET, Uchendu OC, Ajayi TO, Cadmus EO. A review of the health problems of the internally displaced persons in Africa. Nigerian postgraduate medical journal. 2016;23(4):161

24. Mooney E, Martin S, Cohen R, Beau C. When displacement ends: A framework for durable solutions. Washington, DC: The Brookings Institution, University of Bern [Internet]. 2007. Available from: www.brookings.edu/idp.

25. Roberts B, Ocaka KF, Browne J, Oyok T, Sondorp E. Factors associated with posttraumatic stress disorder and depression amongst internally displaced persons in northern Uganda. BMC psychiatry. 2008;8(1):38

26. Durosaro I, Ajiboye S. Problems and coping strategies of internally displaced adolescents in Jos metropolis, Nigeria. International Journal of Humanities and Social Science. 2011;1(20):25662 
Table 1: Socio-demographic characteristics of respondents $(n=240)$

\begin{tabular}{|c|c|c|}
\hline Characteristics & Frequency & $\%$ \\
\hline \multicolumn{3}{|c|}{ Age $(34.47 \pm 11.14$ years } \\
\hline$=20$ & 31 & 12.9 \\
\hline $21-30$ & 76 & 31.7 \\
\hline $31-40$ & 52 & 21.7 \\
\hline $41-50$ & 57 & 23.8 \\
\hline $51-60$ & 24 & 10.0 \\
\hline \multicolumn{3}{|l|}{ Gender } \\
\hline Male & 99 & 41.3 \\
\hline Female & 141 & 58.8 \\
\hline \multicolumn{3}{|l|}{ Religion } \\
\hline Christianity & 92 & 38.3 \\
\hline Islam & 114 & 47.5 \\
\hline Others & 34 & 14.2 \\
\hline \multicolumn{3}{|l|}{ Marital Status } \\
\hline Married & 111 & 46.3 \\
\hline Single & 55 & 22.9 \\
\hline Divorced & 24 & 10.0 \\
\hline Separated & 25 & 10.4 \\
\hline Widowed & 25 & 10.4 \\
\hline \multicolumn{3}{|l|}{ Educational Status } \\
\hline No Formal Education & 89 & 37.1 \\
\hline Primary & 68 & 28.3 \\
\hline Secondary & 55 & 22.9 \\
\hline Tertiary & 28 & 11.7 \\
\hline \multicolumn{3}{|c|}{ Duration of stay in the Camp } \\
\hline 1-4 months & 67 & 27.9 \\
\hline 5-8 months & 88 & 36.7 \\
\hline $9-12$ months & 36 & 15.0 \\
\hline 1 year and above & 49 & 20.4 \\
\hline
\end{tabular}

Table 2: Common Health Problems among the IDPs

\begin{tabular}{lll}
\hline Health Problems & Yes $(\%)$ & No(\%) \\
\hline Malaria disease & $235(97.9)$ & $5(2.1)$ \\
Heart diseases & $136(56.7)$ & $104(43.3)$ \\
Catarrh & $158(65.8)$ & $82(34.2)$ \\
Diarrhoea & $128(53.3)$ & $112(46.7)$ \\
Epidemic outbreak & $194(80.8)$ & $46(19.2)$ \\
\hline
\end{tabular}


Table 3: Hygiene practices of the IDPs $(n=240)$

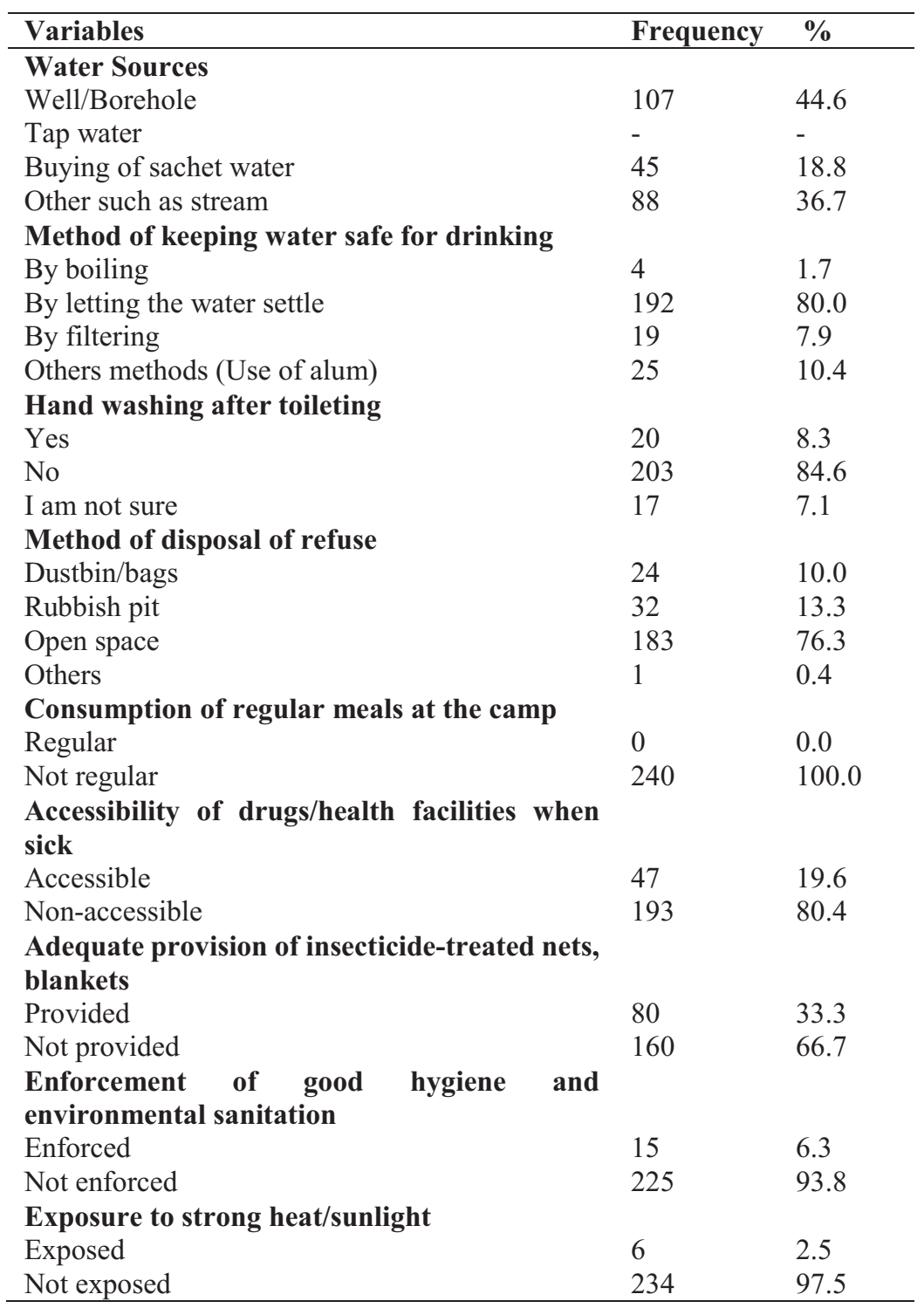

Table 4: General state of the camp

\begin{tabular}{lll}
\hline Overcrowding & Frequenc & \% \\
& y & \\
\hline Always & 110 & 45.8 \\
Sometimes & 116 & 48.4 \\
Never & 14 & 5.8 \\
$\begin{array}{l}\text { Dirty Environment } \\
\text { Always }\end{array}$ & & \\
$\begin{array}{l}\text { Sometimes } \\
\text { Never }\end{array}$ & 131 & 54.6 \\
$\begin{array}{l}\text { Poor Food Distribution } \\
\text { Always }\end{array}$ & 84 & 35.0 \\
$\begin{array}{l}\text { Sometimes } \\
\text { Never }\end{array}$ & 25 & 10.4 \\
Lack of Conducive & & \\
Housing & 16 & 90.0 \\
Always & & 6.7 \\
\hline
\end{tabular}


Table 5: Coping strategies adopted by the IDPs

\begin{tabular}{lll}
\hline Variables & Frequency & $\mathbf{\%}$ \\
\hline Involvement in menial jobs $(\mathbf{n}=\mathbf{2 4 0})$ & & \\
Involved & 68 & 28.3 \\
Not involved & 172 & 71.7 \\
Types of menial jobs involved in $(\mathbf{n}=$ & \\
68) & & \\
Hawking & 14 & 20.6 \\
Digging & 8 & 11.8 \\
Sweeping & 34 & 50.0 \\
Truck pushing & 12 & 17.6 \\
Involvement in Sexual Activities & & \\
Yes & 38 & 15.8 \\
No & 202 & 84.2 \\
\hline
\end{tabular}

Table 6: Health seeking behaviour of the Respondents during illness

\begin{tabular}{lll}
\hline Health seeking behaviour $(\mathbf{n}=\mathbf{2 4 0})$ & Frequency & $\%$ \\
\hline Go to a hospital/health worker & 156 & 65.0 \\
Consult counsellors & 19 & 7.9 \\
Visit Traditional healers & 43 & 17.9 \\
Visit clinic in the neighbouring & 22 & 9.2 \\
village & & \\
Adequacy of Health Facility & 199 & 82.9 \\
No & 41 & 17.1 \\
Yes
\end{tabular}

Table 7: Logistic regressions model predicting the Health Status of the IDPs

\begin{tabular}{lllllll}
\hline Poor health & OR & SE & $\mathbf{Z}$ & $\mathbf{P}>\mathbf{z}$ & \multicolumn{2}{l}{ [95\% C I] } \\
\hline Age & 1.009 & 0.031 & 0.3 & 0.764 & 0.95 & 1.07 \\
Gender & 0.540 & 0.215 & -1.55 & 0.121 & 0.25 & 1.18 \\
Marital Status & 1.381 & 0.403 & 1.11 & 0.268 & 0.78 & 2.45 \\
Educational Status & 0.397 & 0.143 & -2.56 & $\mathbf{0 . 0 1 0}$ & 0.20 & 0.81 \\
Source of water supply & 0.343 & 0.132 & -2.77 & $\mathbf{0 . 0 0 6}$ & 0.16 & 0.73 \\
Hands washing & 7.064 & 4.760 & 2.9 & $\mathbf{0 . 0 0 4}$ & 1.89 & 26.46 \\
Refuse disposal & 0.444 & 0.285 & -1.27 & 0.205 & 0.13 & 1.56 \\
Overcrowding & 0.055 & 0.047 & -3.4 & $\mathbf{0 . 0 0 1}$ & 0.01 & 0.29 \\
\hline
\end{tabular}

$\mathrm{p}$ value in bold is significant at $\mathrm{p}<0.05$ 